\title{
PELAKSANAAN HAK-HAK PASIEN TERHADAP PELAYANAN TENAGA KESEHATAN DI RUMAH SAKIT
}

\author{
Siska Ayu Ningsih \\ Program Studi Keperawan, Stikes Bhakti Husada Bengkulu \\ siskaayuningsih99@gmail.com
}

\begin{abstract}
ABSTRAK
Pasien sebagai pengguna pelayanan kesehatan tentu mempunyai hak-hak yang harus dipenuhi oleh fasilitas penyedia pelayanan dan oleh tenaga pelayanan kesehatan itu sendiri. Penelitian ini bertujuan untuk melihat pelaksanaan hak-hak pasien terhadap pelayanan tenaga kesehatan yang ada di Rumah Sakit Umum Daerah M. Yunus Bengkulu. Penelitian ini merupakan penelitian deskriptif kualitatif. Informan yang menjadi sumber informasi adalah pasien, perawat dan dokter. Data diperoleh dengan wawancara mendalam dan observasi. Hasil penelitian, didapatkan beberapa tema terkait yaitu; pelaksanaan informed concent yang menjadi suatu kewajiban setiap akan dilaksanakan tindakan, adanya beberapa hambatan dalam pemenuhan hak-hak pasien, dan beberapa upaya hukum yang dapat dilakukan oleh pasien jika terdapat wanprestasi terkait pemenuhan hak-hak pasien. Simpulan, Hak-hak pasien untuk memperoleh pelayanan kesehatan yang sebaik-baiknya dari tenaga kesehatan dirasakan masih belum maksimal, Upaya pasien yang haknya tidak terpenuhi atau terjadi suatu pelanggaran yang menimbulkan kerugian terhadap pasien, pasien dapat melaporkan keluhan dan akan ditindaklanjuti oleh pihak rumah sakit. Saran, agar tenaga kesehatan yang melakukan pelayanan kesehatan dapat melayani dengan cepat karena mungkin pasien memerlukan penanganan segera, serta penanganan pertama sesuai dengan kebutuhan pasien sehingga dapat memberikan kepercayaan bahwa pengobatan yang diterima dimulai dan dilakukan secara benar.
\end{abstract}

Kata Kunci: Hak-Hak Pasien, Pelayanan Rumah Sakit, Tenaga Kesehatan

\begin{abstract}
Patients as health service users certainly have rights that must be fulfilled by service provider facilities and by the health service personnel themselves. This study aims to see the implementation of patient rights to the services of health workers at the Regional General Hospital of M. Yunus Bengkulu. This research is a qualitative descriptive study. Informants who become sources of information are patients, nurses and doctors. Data obtained by in-depth interviews and observation. The results of the study found several related themes, namely; the implementation of the informed concent which becomes an obligation every time an action will be carried out, there are several obstacles in fulfilling the patient's rights, and several legal remedies that can be taken by the patient if there are defaults related to the fulfillment of patient rights. In conclusion, the patient's rights to obtain the best possible health care from health workers are still not optimal. The efforts of patients whose rights are not fulfilled or there is a violation that causes harm to the patient, patients can report complaints and will be followed up by the hospital. Suggestions, that health workers who provide health services can serve quickly because the patient may need immediate treatment, as well as the first treatment according to the patient's needs so that it can give confidence that the treatment received is started and carried out correctly.
\end{abstract}


Keywords: Patient Rights, Hospital Services, Health Personnel

\section{PENDAHULUAN}

Kesehatan merupakan hal yang sangat penting dalam kehidupan. Tanpa kesehatan manusia tidak dapat beraktivitas secara optimal. Menyadari arti dan peran penting kesehatan. Pemerintah melalui Departemen Kesehatan turut berperan dalam melaksanakan pembangunan kesehatan yang berkesinambungan dalam upaya bersama-sama mencapai kesehatan yang setinggi-tingginya dengan cara meningkatkan kualitas pelayanan kesehatan di Rumah Sakit. Pelayanan kesehatan yang baik, bermutu, profesional, dan diterima pasien merupakan tujuan utama pelayanan rumah sakit (As'ad Sunggu, 2014).

Berdasarkan UU Nomor 44 Tahun 2009 Tentang Rumah Sakit, Pasal 1; Rumah Sakit adalah institusi pelayanan kesehatan yang menyelenggarakan pelayanan kesehatan perorangan secara paripurna yang menyediakan perawatan rawat inap, rawat jalan, dan gawat darurat. Kondisi Gawat darurat adalah keadaan pasien yang membutuhkan tindakan medis segera, guna menyelamatkan nyawa dan pencegahan kecacatan lebih lanjut. Sedangkan yang dimaksud pelayanan "kesehatan paripurna" adalah pelayanan kesehatan yang meliputi pelayanan kesehatan promotif, preventif, dan rehabilitatif (UU Nomor 44 Tahun 2019 ayat 3).

Jenis pelayanan kesehatan diatas tercantum dalam Undang Undang Nomor 36 Tahun 2009 Tentang Kesehatan Pasal 1, yaitu: Pelayanan kesehatan Promotif adalah suatu kegiatan atau serangkaian kegiatan pelayanan kesehatan yang lebih mengutamakan kegiatan yang bersifat promosi kesehatan. Pelayanan kesehatan preventif adalah suatu kegiatan pencegahan terhadap suatu masalah kesehatan atau penyakit. Pelayanan kesehatan rehabilitatif adalah kegiatan dan serangkaian kegiatan untuk mengembalikan bekas penderita ke dalam masyarakat sehingga dapat berfungsi lagi sebagai anggota masyarakat yang berguna untuk dirinya dan masyarakat semaksimal mungkin sesuai dengan kemampuannya. Pelayanan kesehatan tradisional adalah pengobatan atau perawatan dengan cara dan obat yang mengacu pada pengalaman dan keterampilan turun temurun serta empiris yang dapat dipertanggungjawabkan dan diterapkan sesuai dengan norma yang berlaku di masyarakat (UU Nomor 36 Tahun 2009 tentang Kesehatan, Pasal 1).

Pelayanan kesehatan disediakan oleh dokter, perawat, dan tenaga ahli kesehatan lainnya. Tenaga ahli kesehatan adalah setiap orang yang mengabdikan diri dalam bidang kesehatan serta memiliki pengetahuan dan keterampilan melalui pendidikan dibidang kesehatan yang untuk jenis tertentu memerlukan kewenangan untuk melakukan upaya kesehatan (UU Nomor 36 Tahun 2009 tentang Kesehatan, ayat 6). Setiap tenaga kesehatan yang bekerja di rumah sakit harus bekerja dengan standar profesi, standar pelayanan rumah sakit, standar prosedur operasional yang berlaku, etika profesi, menghormati hak pasien dan mengutamakan keselamatan pasien (UU No 44 Tahun 2009 Tentang Rumah Sakit).

Hak pasien dalam Undang Undang Rumah Sakit tercantum pada Pasal 32, Setiap pasien mempunyai hak, diantaranya; 1) Memperoleh informasi mengenai tata tertib dan peraturan yang berlaku di Rumah Sakit; 2) Memperoleh informasi tentang hak dan kewajiban pasien; 3) Memperoleh pelayanan yang menusiawi, adil, jujur, dan tanpa diskriminasi; 4) Memperoleh pelayanan kesehatan yang bermutu sesuai dengan standar profesi dan standar prosedur operasional; 5) Memperoleh pelayanan 
yang efektif dan efisien sehingga pasien terhindar dari kerugian fisik dan materi; 6) Mengajukan pengaduan atas kualitas pelayanan yang didapatkan.

Pemerintah turut berperan dalam mengawasi pelayanan kesehatan di rumah sakit dengan mengatur adanya komite medik. Komite medik adalah perangkat rumah sakit untuk menerapkan tata kelola klinis (clinical governance) agar staf medis di rumah sakit terjaga profesionalismenya melalui mekanisme kredensian, penjagaan mutu profesi medis, dan pemeliharaan etika dan disiplin profesi medis (Bhekti Suryani, 2013). Komite medik merupakan organisasi non struktural yang dibentuk dirumah sakit oleh kepala atau direktur rumah sakit. Ketentuan mengenai perencanaan, pengadaan, pendayagunaan, pembinaan dan pengawasan mutu tenaga kesehatan diatur dalam Peraturan Pemerintah (Soekidjo Notoatmodjo dalam Bhekti Suryani, 2013).

Penyelenggaraan pelayanan

kesehatan dilaksanakan secara bertanggungjawab, aman, bermutu, merata dan nondiskriminatif. Setiap orang berhak menerima atau menolak sebagian atau seluruh tindakan pertolongan yang akan diberikan kepadanya setelah menerima dan memahami informasi mengenai tindakan yang akan diberikan tenaga kesehatan tersebut secara lengkap. Pasien dalam pelayanan medis merupakan orang yang memerlukan pertolongan dokter karena penyakitnya. Sedangkan dokter adalah orang yang akan memberikan pertolongan karena kemampuan profesinya yang dianggap mampu mengobati penyakit.

Harus diakui masyarakat Indonesia masih belum terbiasa secara aktif mendapatkan informasi dalam penggunaan pelayanan medis. Umumnya pasien menyerahkan sepenuhnya kepada dokter mengenai pelayanan medis yang akan diterima oleh dirinya. Hubungan hukum yang terjadi antara dokter dan pasien terjadi ketika dokter menerima pasiennya. Hubungan ini pada umumnya berada dalam posisi yang tidak seimbang. Disatu sisi ada orang yang memerlukan pertolongan yaitu pasien dan orang yang diharapkan memberikan pertolongan yaitu dokter. Dalam hubungan yang demikian, dokter diharapkan akan bersikap bijaksana dan tidak memanfaatkan kelemahan pasien sebagai keuntungan bagi dirinya sendiri.

Pelaksanaan peran, baik itu merupakan hak maupun kewajiban ataupun kekuasaan, akan selalu melahirkan suatu tanggung jawab baik diminta ataupun tidak diminta selain itu dokter juga memiliki kewajiban moral untuk menghormati hak pasiennya sebagai manusia (Danny Wiradharma, 1996).

Hak-hak yang dimiliki pasien tersebut juga tercantum pada UndangUndang Nomor 29 Tahun 2004 tentang Praktik Kedokteran, yang berisi: hak-hak pasien adalah mendapatkan penjelasan secara lengkap tentang tindakan medis, meminta pendapat dokter, dokter gigi dan dokter dibidang lain, mendapatkan pelayanan sesuai dengan kebutuhan medis, menolak tindakan medis, dan mendapatkan isi rekam medis.

Pasien sebagai orang yang memiliki masalah kesehatan berhak memperoleh pelayanan kesehatan yang sebaik-baiknya, tenaga kesehatan harus mendahulukan pelayanan kesehatan sebagai bentuk pengabdiannya terhadap masyarakat dari pada kepentingan pribadi. Dalam menjalankan tugasnya, bagi dokter berlaku "Aegroti Salus Lex Suprema", yang berarti keselamatan pasien adalah hukum yang tertinggi (Jusuf Hanafiah \& Amri Amir, 2013).

Tetapi yang terjadi ketika pasien rawat inap di Rumah Sakit membutuhkan penanganan khusus diwaktu yang tidak dapat ditentukan, dokter sebagai pemberi pelayanan medis terhadap pasien tidak berada di tempat Salah satu contoh tentang lemahnya pemenuhan hak pasien 
di Rumah Sakit Umum Daerah M. Yunus Bengkulu ditemukan pasien yang membutuhkan penanganan khusus oleh dokter, tetapi dokter tidak berada ditempat. Contoh kasus keluarga pasien yang membutuhkan penanganan medis yaitu ibu rinda istri dari bapak ramon yang mengalami penyakit lupus, keadaan istri bukan semakin membaik tapi semakin parah diajak berbicara tidak nyambung, respon perawat lambat dan perawat kurang bisa menghargai pasien dan itu terjadi di ruangan kenanga di Rumah Sakit Umum Daerah M.Yunus Bengkulu. wawancara terhadap keluarga pasien yang tidak terpenuhi haknya, Ny. Junaida di Rumah Sakit Umum Daerah M Yunus Bengkulu yang dilakukan pada 21 Oktober2014.

Dengan adanya masalah dan uraian di atas penulis memilih untuk melakukan penelitian mengenai pelaksanaan hak-hak pasien dan upaya yang dilakukan jika hak pasien tidak terpenuhi terhadap pelayanan tenaga kesehatan di Rumah Sakit. Adapun tujuan penelitian ini adalah untuk mengetahui pelaksaan pemenuhan hakhak pasien Terhadap Pelayanan Tenaga Kesehatan Di Rumah Sakit Umum Daerah M. Yunus Bengkulu.

\section{METODE PENELITIAN}

Penelitian ini menggunakan penelitian hukum empiris, dengan tujuan melihat kenyataan langsung dilapangan, dan menjadi objek penelitian yang kaitannya dengan pelaksanaan hak-hak pasien terhadap pelayanan tenaga kesehatan di Rumah Sakit Umum Daerah M. Yunus Bengkulu. Sesuai dengan bidang penelitian hukum empiris, maka pendekatan masalah yang dapat digunakan adalah pendekatan perilaku (behavioral approach) (Abdul Kadir, 2004).

Penelitian ini dilakukan di Rumah Sakit Umum Daerah M. Yunus Bengkulu. Yang menjadi populasi dalam penelitian ini adalah semua pihak yang berhubungan dengan objek penelitian yaitu dokter dan perawat di Rumah Sakit Umum Daerah M. Yunus Bengkulu, serta pasien yang sedang dirawat di Rumah Sakit Umum Daerah M. Yunus Bengkulu.

Teknik penentuan sampel dalam penelitian ini menggunakan metode Random sampling. Sumber data dalam penelitian ini adalah Sumber data primer yang diperoleh secara langsung dari informan dan sumber data sekunder yang diperoleh dari bahan-bahan kepustakaan. Sumber data sekunder yang digunakan dalam penelitian ini berasal dari peraturan perudang-undangan seperti Undang-Undang Nomor 29 Tahun 2004 tentang Praktik Kedokteran, UndangUndang Nomor 36 Tahun 2009 tentang Kesehatan, Undang-Undang Nomor 44 Tahun 2009 tentang Rumah Sakit, bukubuku, dan literature yang berhubungan dengan penelitian.

Pengumpulan data primer dalam penelitian ini menggunakan teknik wawancara, sedangkan data sekunder diperoleh dengan mempelajari perundang-undangan, buku-buku, dan Tesis yang berkaitan dengan pokok masalah yang diteliti. Analisis data yang dilakukan yaitu dengan mendeskripsikan kata-kata hasil wawancara dan studi literatur yang menggunakan kerangka berfikir deduktif dan induktif serta sebaliknya.

\section{HASIL PENELITIAN}

Prakontrak Sebelum Di Berikannya Pelayanan Kesehatan Oleh Pihak Rumah Sakit Umum Daerah M.Yunus Bengkulu

Pelayanan kesehatan di Rumah Sakit Umum Daerah M.Yunus Bengkulu dilengkapi dengan fasilitas pelayanan medis serta didukung oleh sumber daya manusia yang profesonal. Adapun yang harus dilaksanakan oleh pasien sebelum dilakukannya perjanjian rawat inap di Rumah Sakit Umum Daerah M.Yunus Bengkulu adalah pihak pasien dan pihak 
rumah sakit bernegosiasi secara lisan terkait perjanjian yang akan disepakati mengenai biaya perawatan selama pasien dirawat di rumah sakit.

Kesepakatan antara pihak pasien dan pihak rumah sakit dimuat dalam suatu perjanjian. Perjanjian rawat inap yang terjadi antara pihak pasien dengan pihak Rumah Sakit Umum Daerah M.Yunus Bengkulu yang dibuat secara tertulis, tidak pernah diberikan secara lisan. Perjanjian ini merupakan perjanjian standar atau baku (Standard contract) perjanjian ini bentuknya tertulis berupa formulir-formulir yang isinya telah distandarisasi atau dibakukan terlebih dahulu secara sepihak oleh produsen, serta bersifat masal, tanpa mempertimbangkan perbedaan kondisi yang dimiliki oleh konsumen (Djaja S. Meliala, 2012).

Kontrak ini tidak terlepas dari ketentuan hukum yang terdapat dalam Pasal 1320 Kitab Undang-Undang Hukum Perdata yang telah mengatur tentang syarat sahnya suatu perjanjian, yaitu; 1) kesepakatan mereka yang mengikatkan dirinya; 2) kecakapan untuk membuat suatu perikatan; 3) suatu pokok persoalan tertentu; 4) suatu sebab yang tidak terlarang.

Sehubungan dengan perjanjian pasien yang diberikan terhadap pihak Rumah Sakit melalui perjanjian tertulis yang dikenal dengan istilah informed consent yaitu kesepakatan atau persetujuan pasien atas usaha medis yang dilakukan untuk menolong dirinya disertai informasi atas segala resiko yang mungkin terjadi. Keberadaan informed consent pada hakikatnya merupakan penerapan asas setiap manusia mempunyai hak untuk berperan serta dalam mengambil keputusan dalam menyangkut dirinya sendiri. Begitupun pasien yang ingin mengikatkan diri terhadap kontrak yang akan disetujuinya dalam perjanjian tertulis tersebut.

Berdasarkan teori dan beberapa pendapat mengenai informed consent, maka informed consent merupakan bentuk kesepakatan antara dokter dan pasien dalam melakukan suatu tindakan medik, yaitu dalam bentuk formulir sebagai proses komunikasi dalam mencapai suatu kesepakatan, apakah pasien menerima suatu tindakan medik yang diberikan dokter ataupun menolaknya berdasarkan hak pasien. Penandatanganan persetujuan dilaksanakan oleh pasien atau keluarga pasien dengan petugas di instalasi administrasi rumah sakit. Instalasi administrasi merupakan unit pelayanan yang menyelenggarakan kegiatan administrasi pasien, diantaranya informasi tentang identitas pasien, perhitungan perincian tagihan biaya perawatan layanan pasien rawat inap, serta prosedur pelayanan bagi pasien rawat inap (Nydia Andriani, 2014).

Tujuan dari kegiatan administrasi yang dilakukan di rumah sakit antara lain; 1) Menentukan persyaratan pasien bisa masuk ke rumah sakit; 2) Menerima pasien yang akan masuk bangsal rawat inap; 3) Memproses perpindahan pasien antar bangsal perawatan di dalam rumah sakit tersebut, antar rumah sakit dan tempat pelayanan kesehatan lainnya; 4) Memproses pemulangan pasien dan kematian pasien; 5) Memberikan konsultasi keuangan kepada pasien sebelum atau pada awal pendaftaran (Nydia Andriani, 2014).

Setelah pihak pasien menandatangani atau memberikan persetujuan atas perjanjian terapeutik, maka pasien atau keluarga pasien menyerahkan bukti penandatanganan disertai kartu tanda pengenal pasien kepada pihak administrasi Rumah Sakit Umum M.Yunus Bengkulu (Pasien, Ny. Dahniar, 27 Juli 2015).

$\begin{array}{llr}\begin{array}{l}\text { Pelaksanaan } \\ \text { Terhadap }\end{array} & \begin{array}{c}\text { Hak-Hak } \\ \text { Pelayanan }\end{array} & \begin{array}{r}\text { Pasien } \\ \text { Tenaga }\end{array} \\ \text { Kesehatan Di Rumah Sakit } & \text { Umum } \\ \text { Daerah M.Yunus Bengkulu } & \end{array}$


Hak-hak pasien yang diperoleh dari Rumah Sakit ditinjau dari UndangUndang Nomor 36 tahun 2009 tentang Kesehatan. Pasal 56 yang berbunyi;

(1) Setiap orang berhak menerima atau menolak sebagian atau seluruh tindakan atau pertolongan yang akan diberikan kepadanya setelah menerima dan memahami informasi mengenai tindakan tersebut secara lengkap.

(2) Hak untuk menerima atau menolak sebagaimana dimaksudkan pada ayat

(1) tidak berlaku pada :
a. Penderita penyakit yang penyakitnya dapat secara cepat menular ke dalam masyarakat yang lebih luas.
b. Keadaan seseorang yang tidak sadarkan diri.
c. Gangguan mental berat.

(3) Ketentuan mengenai hak menerima atau menolak sebagaimana dimaksud pada ayat 1 diatur sesuai dengan ketentuan perundang-undangan.

Pasal 57 :

(1) Setiap orang bersedia atas rahasia kondisi kesehatan pribadinya yang telah dikemukakan kepada penyelenggara pelayanan kesehatan.

(2) Ketentuan mengenai hak atas rahasia kondisi kesehatan pribadi sebagaimana dimaksud pada ayat 1 tidak berlaku dalam :
a. Perintah Undang-Undang
b. Perintah pengadilan
c. Izin yang bersangkutan
d. Kepentingan masyarakat; dan
e. Kepentingan orang tersebut.

Pasal 58 :

(1) Setiap orang berhak menuntut ganti rugi terhadap seseorang, tenaga kesehatan, dan/atau penyelenggara kesehatan yang menimbulkan kerugian akibat kelalaian atau kesalahan dalam pelayanan kesehatan yang diterimanya.
(2) Tuntutan ganti rugi sebagaimana telah diatur pada ayat 1 tidak berlaku bagi tenaga kesehatan yang melakukan tindakan penyelamatan nyawa atau pencegahan kecacatan orang dalam keadaan darurat.

(3) Keadaan mengenai tata cara pengajuan tuntutan sebagaimana dimaksud pada ayat 1 diatur sesuai dengan ketentuan peraturan perundang-undangan.

Pada Undang-Undang Nomor 44 Tahun 2009 tentang Rumah Sakit Pasal 32 memuat tentang hak-hak yang dimiliki oleh pasien, diantaranya; 1) Memperoleh informasi mengenai tata tertib dan peraturan yang berlaku di Rumah Sakit; 2) Memperoleh informasi tentang hak dan kewajiban pasien; 3) Memperoleh pelayanan yang manusiawi, adil, jujur, dan tanpa diskriminasi; 4) Memperoleh pelayanan kesehatan yang bermutu sesuai dengan standar profesi dan standar prosedur operasional; 5) Memperoleh pelayanan yang efektif dan efisien sehingga pasien terhindar dari kerugian fisik dan materi; 6) Mengajukan pengaduan atas kualitas pelayanan yang didapatkan.

Dari isi Undang-Undang Nomor 44 tahun 2009 tentang Rumah Sakit yang memuat tentang pasien berhak memperoleh pelayanan kesehatan yang bermutu sesuai dengan standar profesi dan prosedur operasional serta mendapatkan pelayanan kesehatan yang efektif dan efisien sehingga pasien terhindar dari kerugian fisik dan materi di rumah sakit. Sedangkan pada Pasal 58 Undang-Undang Nomor 36 tentang Kesehatan mengatur tentang perlindungan pasien terhadap pelayanan kesehatan yang telah diberikan oleh pihak Rumah Sakit. Pelayanan kesehatan terhadap pasien dengan penuh tanggung jawab, aman, dan bermutu tentu tidak dapat terwujud tanpa adanya tenaga ahli kesehatan yang profesional dalam sebuah instansi rumah sakit, diantaranya tersedia 
tenaga tetap medis seperti dokter, perawat dan paramedis.

Pelaksanaan pelayanan kesehatan terhadap pasien di Rumah Sakit Umum Daerah M.Yunus tidak terlepas dari adanya komitmen dari perawat untuk memberikan pelayanan terbaik kepada pasien. Pelayanan keperawatan di rumah sakit merupakan suatu faktor penentu bagi mutu pelayanan rumah sakit dimata masyarakat. Kinerja perawat dapat dilihat dari pelayanan yang diberikannya terhadap pasien di rumah sakit, karena perawat ialah tenaga kesehatan yang paling dekat dengan pasien selama 24 jam. Selain perawat, dokter yang merupakan tenaga ahli kesehatan yang memiliki wewenang dan tanggung jawab memeriksa dan memberikan pelayanan kesehatan terhadap pasien rawat inap di Rumah Sakit Umum Daerah M.Yunus Bengkulu.

Dari hasil wawancara penulis terhadap dua belas pasien di Ruangan melati, kenanga dan seruni Rumah Sakit Umum M.Yunus Bengkulu. Hak pasien di Rumah Sakit Umum Daerah M.Yunus Bengkulu diatur dalam Undang-Undang Nomor 44 Tahun 2009 tentang Rumah Sakit. Pertama, hak pasien itu adalah berhak mendapatkan informasi tentang tata tertib dan peraturan yang berlaku dirumah sakit, memperoleh informasi tentang hak dan kewajiban pasien. Pihak Rumah Sakit Umum Daerah M.Yunus Bengkulu telah memberikan informasi tersebut secara tertulis.

Kedua, hak mendapatkan pelayanan medis bermutu sesuai dengan standar profesi dan standar prosedur operasional. Pihak Rumah Sakit Umum Daerah M.Yunus Bengkulu memberikan pelayanan dengan menyediakan dokter bedah, dokter umum, dan perawat. Ketiga, hak pasien mendapatkan pelayanan yang efektif dan efisien sehingga pasien terhindar dari kerugian fisik dan materi. Pada kenyataan yang terjadi di Rumah Sakit Umum Daerah M.Yunus, banyak kejadian-kejadian yang tiba-tiba muncul terhadap pasien yang sangat membutuhkan pertolongan dari tenaga medis pada waktu tertentu, sedangkan yang terlihat masih kurang efektifnya pelayanan kesehatan yang diberikan, jam besuk dokter terhadap pasien rawat inap serta minimnya jumlah dokter jaga yang bertugas di Rumah Sakit Umum M.Yunus Bengkulu menyebabkan terjadinya berbagai masalah yang dikeluhkan oleh pasien.

Keempat, hak pasien memilih dokter dan kelas perawatan sesuai dengan yang diinginkan, pihak Rumah Sakit Umum Daerah M.Yunus menyediakan kelas perawatan sesuai dengan yang diinginkan pasien dan pada kenyataannya dokter yang menangani pasien di Rumah Sakit Umum Daerah M.Yunus merupakan dokter spesialis yang telah ditentukan oleh rumah sakit seuai dengan jenis penyakit yang diderita oleh pasien. Kelima, hak pasien meminta konsultasi tentang penyakit yang dideritanya kepada dokter lain yang memiliki (SIP) baik di dalam maupun di luar rumah sakit. pihak Rumah Sakit Umum Daerah M.Yunus tidak pernah memberikan larangan terhadap pasien terkait konsultasi yang dilakukan pasien terhadap dokter lain.

Keenam, hak pasien mendapatkan informasi yang meliputi diagnosis dan tata cara tindakan medis, tujuan tindakan, alternatif tindakan, resiko dan komplikasi yang kemungkinan terjadi, dan perkiraan biaya pengobatan. Pihak Rumah Sakit Umum Daerah M.Yunus memberikan informasi mengenai diagnosis, dan tujuan tindakan serta perkiraan biaya pengobatan pada bagian administrasi rumah sakit, dan pada kenyataan yang terjadi pasien mengeluh atas lamanya menunggu hasil diagnosis mengenai penyakit yang diderita oleh pasien sehingga pasien harus menunggu setelah itu baru mendapatkan tindakan medis selanjutnya.

Ketujuh, hak memberikan persetujuan dan penolakan tindakan medis yang akan dilakukan terhadap 
penyakit yang dideritanya. Pihak rumah sakit telah mempersiapkan surat persetujuan ataupun penolakan tindakan medis (Informed consent). Kedelapan, hak pasien didampingi keluarga dalam keadaan kritis, pihak Rumah Sakit Umum Daerah M.Yunus mempersilahkan satu orang anggota keluarga pasien yang mendampingi pasien dalam keadaan kritis.

Kesembilan, hak pasien mengadukan keluhan terhadap pelayanan rumah sakit yang tidak sesuai dengan standar pelayanan kesehatan dan keluhan yang dialami pasien. Pengaduan pasien di Rumah Sakit Umum Daerah M.Yunus Bengkulu dapat dilakukan dengan memberikan surat keluhan dalam kotak saran yang telah disediakan oleh pihak Rumah Sakit Umum Daerah M.Yunus Bengkulu.

Keselamatan pasien merupakan hal yang paling utama dalam setiap rumah sakit. Masyarakat tentunya memiliki pandangan bahwa keterlambatan pelayanan yang dilakukan oleh tenaga kesehatan akan menjadikan penentu bagi mutu yang diberikan terhadap pasien dan pada dasarnya akan menjadi acuan dalam menilai kualitas pelayanan yang diberikan oleh rumah sakit dimata masyarakat.

\section{PEMBAHASAN}

\section{Hambatan Pemenuhan Hak Pasien di Rumah Sakit Umum Daerah M.Yunus Bengkulu}

Penerapan Undang-Undang Nomor 44 tahun 2009 tentang Rumah Sakit yang memuat tentang pasien berhak memperoleh pelayanan kesehatan yang bermutu sesuai dengan standar profesi dan prosedur operasional, serta mendapatkan pelayanan kesehatan yang efektif dan efisien sehingga pasien terhindar dari kerugian fisik dan materi di Rumah Sakit. Dalam memberikan pelayanan, Rumah Sakit Umum Daerah M.Yunus telah mengutamakan kepentingan Pasien sesuai dengan standar pelayanan di Rumah Sakit dan melaksanakan fungsi sosial antara lain memberikan fasilitas pelayanan pasien kepada yang tidak mampu/miskin, pelayanan gawat darurat tanpa uang muka, pelayanan korban bencana dan kejadian luar biasa dan bukti sebagai misi kemanusiaan. Oleh karena itu, rumah sakit mengutamakan kesehatan dan keselamatan pasien tanpa melihat status sosial pasien tersebut.

Keselamatan pasien diatur pula dalam Peraturan Menteri Kesehatan Indonesia Nomor. 1691/ MENKES/ PER/VIII/2011 tentang Keselamatan Pasien Rumah Sakit. Dalam Pasal 1 angka 1 menyatakan bahwa, keselamatan pasien rumah sakit adalah suatu sistem dimana rumah sakit membuat asuhan pasien lebih aman yang meliputi assemen resiko, identifikasi, dan pengelolahan hal yang berhubungan dengan resiko pasien, pelaporan dan analisis insiden dan tindak lanjutnya serta implementasi solusi untuk meminimalkan timbulnya resiko dan mencegah terjadinya cedera yang disebabkan oleh kesalahan akibat melaksanakan suatu tindakan atau tidak mengambil tindakan yang seharusnya diambil.

Dalam membangun kesadaran akan nilai keselamatan pasien merupakan hak bagi pasien dan kewajiban rumah sakit. Pasien berhak mendapatkan pelayanan kesehatan yang efektif dan efisien sebagaimana telah tercantum dalam Undang-Undang Nomor 44 tahun 2009 Tentang Rumah Sakit. Hasil wawancara dengan pihak dokter, bahwa dokter juga bertanggung jawab dalam keselamatan pasien. Tindakan yang dilakukan sama sesuai spesialis penyakit yang diderita oleh pasien. Jumlah Dokter di ruangan Melati terdiri dari 5 orang dokter spesialis (hasil Wawancara Yanasari, dokter, 27 Juli 2015).

Jadwal dokter yang masuk ke ruangan melati, bogenvil, anggrek, dan seruni telah diatur oleh Kepala Staf Medik Fungsional yaitu Bapak Salius 
Sili. Wawancara dengan Rahma, Kepala Ruangan Melati (29 Juli 2015). Staf Medik Fungsional adalah kelompok dokter yang bekerja dibidang medis dalam jabatan fungsional yang berada dibawah dan bertanggung jawab kepada direktur utama. Staf Medik Fungsional mempunyai tugas melaksanakan diagnosa, pengobatan, pencegahan akibat penyakit, peningkatan dan pemulihan kesehatan, penyuluhan, pendidikan, pelatihan, dan pengembangan (Amir Syamsudin, 2018).

Sedangkan jumlah seluruh perawat di ruangan Melati ada 22 perawat yang disebut sebagai perawat laksana, yaitu perawat yang bertugas secara bergantian, pada saat pagi, sore, dan malam (Hasil wawancara dengan Yhuni, Perawat, 9 febuari 2018) Menurut perawat, perawat jaga pada malam hari berjumlah empat orang, apabila pasien lebih dari 30 orang, maka perawat jaga akan ditambah menjadi lima orang. Menurut data yang diperoleh dari hasil penelitian penulis, ada beberapa hambatan yang sering terjadi dalam memenuhi hak pasien terhadap pelayanan tenaga kesehatan yang diberikan oleh Rumah Sakit Umum M.Yunus, antara lain; 1) Kurangnya jam besuk dokter terhadap pasien yang sedang menjalani perawatan rawat inap di Rumah Sakit Umum Daerah M.Yunus Bengkulu; 2) Kurangnya jumlah dokter jaga di Rumah Sakit Umum Daerah M.Yunus terutama pada malam hari; 3) Sering terjadi keterlambatan pemberitahuan hasil diagnosa terhadap penyakit yang dialami pasien di Rumah Sakit Umum Daerah M.Yunus Bengkulu; 4) Pelayanan perawat yang kurang komunikatif terhadap pasien di Rumah Sakit Umum Daerah M.Yunus Bengkulu. Pasien sebagai masyarakat yang memiliki hak untuk mendapatkan pelayanan yang sebaik-baiknya sangat mengeluhkan kurangnya tenaga dokter yang berada di ruangan khususnya pada saat malam hari.

\section{Upaya Hukum Yang Dapat Dilakukan Pasien Terhadap Hak Yang Tidak Terlaksana di Rumah Sakit Umum Daerah M.Yunus Bengkulu}

Dalam memberikan pelayanan kesehatan masyarakat, apabila terjadi wanprestasi, akan diselesaikan melalui musyawarah dan perdamaian dengan meyakinkan pihak pasien maupun keluarga, bahwa apa yang dilakukan oleh dokter telah sesuai dengan prosedur tindakan medik. Wawancara dengan Rahma, Kepala Ruangan (27 Januari 2018) Dokter dalam melakukan praktik akan diawasi untuk meningkatkan mutu pelayanan kesehatan, dan melindungi pasien dari tindakan yang dilakukan dokter di Rumah Sakit Umum Daerah M.Yunus Bengkulu.

Pasien mempunyai hak untuk melaporkan keluhan terhadap pelayanan rumah sakit yang tidak sesuai dengan standar pelayanan kesehatan, dan keluhan atas kualitas pelayanan yang dialami pasien. Pengaduan pasien tersebut dapat dilakukan dengan memberikan surat keluhan dalam kotak saran yang telah disediakan pihak Rumah Sakit Umum Daerah M.Yunus Bengkulu (hasil wawancara dengan Novita, Kepala Instalasi IRNA, 21 febuari 2018).

Pertanggung jawaban atas pelayanan medis harus dilakukan penelitian terlebih dahulu, apabila kesalahan dilakukan oleh dokter, maka rumah sakit bertanggungjawab secara umum dan dokter sebagai pelaksana tindakan medis dapat dikenakan sanksi. Seorang dokter harus membandingkan tujuan tindakan medik dengan resiko dari tindakan tersebut dengan resiko yang terkecil (Hasil wawancara dengan Dewi, Dokter, 27 januari 2018).

Selain itu peraturan tentang ganti rugi juga tertulis pada Undang-Undang Nomor 36 Tahun 2009 tentang Kesehatan pada Pasal 58 yang berbunyi ; 1) setiap orang berhak menuntut ganti rugi terhadap seseorang tenaga kesehatan dan/atau penyelenggaraan kesehatan yang 
menimbulkan kerugian akibat kesalahan atau kelalaian dalam pelayanan kesehatan yang diterimanya; 2) Tuntutan ganti rugi sebagaimana dimaksud pada ayat (1) tidak berlaku bagi tenaga kesehatan yang melakukan tindakan penyelamatan nyawa atau pencegahan kecacatan seseorang dalam keadaan darurat; 3) Ketentuan mengenai tata cara pengajuan tuntutan sebagaimana dimaksud pada ayat (1) diatur sesuai dengan ketentuan peraturan perundang-undangan.

Berdasarkan penelitian penulis mengenai tanggung jawab yang dilakukan pihak rumah sakit apabila terjadi pelayanan yang tidak sesuai dengan peraturan di rumah sakit oleh dokter, maka pasien yang menderita kerugian dapat menuntut ganti rugi kepada pihak rumah sakit. Pasien yang merasa dirugikan atas pelayanan kesehatan dapat menyampaikan pengaduan kepada direktur Rumah Sakit, kemudian ke komite medik dengan memberikan keterangan mengenai hal yang diadukan atau dirugikan dari pelayanan dokter atau tenaga medis lainnya, kemudian Direktur Rumah Sakit akan memanggil kedua belah pihak yaitu pasien dan dokter untuk dimintai keterangan tentang masalah apa yang terjadi diantara keduanya dan akan mencari penyelesaian masalahnya melalui mediasi, sesuai dengan Pasal 29 Undang-Undang Nomor 36 Tahun 2009 tentang Kesehatan yang berisi Dalam hal tenaga kesehatan diduga melakukan kelalaian dalam menjalankan profesinya, kelalaian tersebut harus diselesaikan terlebih dahulu melalui mediasi.

Apabila terbukti bahwa kerugian yang diderita oleh pasien diakibatkan oleh kelalaian dokter, maka yang bertanggungjawab atas kerugian tersebut adalah dokter atau rumah sakit sesuai dengan keputusan yang diambil oleh direktur rumah sakit. Wawancara dengan Sri Utari, dokter (28 Januari 2018). Apabila pasien tidak puas atas keputusan yang diambil direktur rumah sakit, atau tidak ada pemecahan masalah, maka pasien yang mengalami pelanggaran pelayanan kesehatan oleh pihak rumah sakit dapat melaporkan sengketa tersebut dapat melaporkan sengketa tersebut ke Dinas Kesehatan atau Ikatan Dokter Indonesia (IDI) Bengkulu agar sengketa tersebut dapat segera diselesaikan. Apabila tetap tidak menemukan pemecahan masalah atas sengketa tersebut, maka pasien dapat mengadukan hal tersebut kepada pihak MKDKI atau Majelis Kehormatan Disiplin Kedokteran Indonesia sesuai dengan Pasal 66 ayat (1) Undang-Undang Nomor 29 Tahun 2004 tentang Kedokteran untuk selanjutnya ditindak lanjuti.

Keputusan MKDKI melalui sidang pengadilan disiplin dapat menyatakan bahwa yang diadukan tidak bersalah atau bersalah dengan pemberian sanksi disiplin. Sanksi disiplin bisa berupa peringatan tertulis, rekomendasi pencabutan tanda registrasi/izin praktik tau mewajibkan mengikuti pendidikan atau pelatihan di institusi pendidikan, dan dalam sidang ini dilakukan oleh hakim adhoc. Selain itu, pengaduan tidak tertulis dibuat oleh pengadu kepada MKDKI, tidak menutup hak setiap orang untuk melaporkan adanya dugaan tindak pidana kepada pihak yang berwenang atau menggugat kerugian ke pengadilan. Apabila dalam pemeriksaan ditemukan pelanggaran etika, maka MKDKI meneruskan ke organisasi profesi, yaitu IDI atau Ikatan Dokter Indonesia (Jusuf Hanafia \& Amri Amir, 2013).

Pengaduan harus memenuhi persyaratan sesuai dengan Peraturan Konsil Kedokteran Indonesia Nomor 2 Tahun 2011 tentang Tata Cara Penanganan Kasus Dugaan Pelanggaran Disiplin Dokter dan Dokter Gigi, yaitu:

1) Orang atau badan yang mengadukan (pengadu), dokter atau dokter gigi dan peristiwa yang diadukan harus mengetahui adanya dugaan pelanggaran disiplin dokter atau dokter gigi. Kepentingannya 
dirugikan atas tindakan dokter atau dokter gigi dalam menjalankan praktik kedokteran. Bila ia menunjuk kuasa pengadu, mka harus membuat surat kuasa.

2) Peristiwa yang diadukan terjadi setelah diundangkannya UndangUndang Nomor 29 tahun 2004 tentang Praktik kedokteran pada tanggal 6 oktober 2004.

3) Peristiwa yang diadukan tidak dimaksudkan untuk penyelesaian atas tuntutan ganti rugi.

4) Keterangan atau informasi dalam pengaduan memuat :

a. Identitas pengadu.

b. Identitas pasien.

c. Nama dan alamat lengkap dokter atau dokter gigi yang diadukan, STR dan SIP dokter atau dokter gigi yag diadukan.

d. Waktu tindakan dilakukan.

e. Alasan pengaduan yang memuat kronologis peristiwa yang diadukan.

f. Nama saksi-saksi dan keterlibatannya (jika ada).

5) Pengaduan dilakukan secara tertulis. Bila tidak mampu mengadukan secara tertulis dapat mengadukan secara lisa yang dilakukan di kantor MKDKI.

6) Belum pernah diadukan atau diperiksa oleh Dinas Kesehatan Provisi bagi peristiwa yang diadukan yang terjadi pada masa peralihan sebelum terbentuknya MKDKI dan setelah diundangkannya UndangUndang Nomor 29 Tahun 2004 tentang Praktik Kedokteran (Bhekti Suryani, 2013).

Apabila laporan pengaduan yang masuk memenuhi persyaratan, MKDKI akan menindak lanjutinya dengan melakukan pemeriksaan, bila kemudian ditemukan pelanggaran etika, lembaga ini akan meneruskan pengaduan ke organisasi profesi. Keputusan MKDKI bersifat mengikat. Keputusan yang dimaksud dapat berupa pernyataan tidak bersalah atau memberi sanksi disiplin (Bhekti Suryani, 2013). Selain mengadu ke MKDKI karena adanya pelanggaran disiplin, masyarakat juga berhak melaporkan adanya dugaan tindak pidana kepada pihak berwenang, atau menggugat kerugian perdata ke pengadilan.

\section{KESIMPULAN}

Berdasarkan pembahasan yang telah penulis kemukakan di atas, dapat ditarik kesimpulan, bahwa; 1) Hak-hak pasien untuk memperoleh pelayanan kesehatan yang sebaik-baiknya dari tenaga kesehatan di Rumah Sakit Umum Daerah M.Yunus Bengkulu dirasakan masih belum maksimal; 2) Upaya pasien yang haknya tidak terpenuhi, pasien dapat melaporkan keluhan terhadap pelayanan rumah sakit yang tidak sesuai dengan standar pelayanan kesehatan, dan keluhan atas kualitas pelayanan yang dialami pasien. Pengaduan pasien tersebut dapat dilakukan dengan memberikan surat keluhan dalam kotak saran yang telah disediakan.

Pasien yang merasa dirugikan atas pelayanan kesehatan dapat menyampaikan pengaduan kepada Direktur Rumah Sakit, kemudian ke Komite Medik dengan memberikan keterangan mengenai hal yang diadukan atau dirugikan. Pasien yang tidak puas dengan keputusan direktur rumah sakit, dapat melaporkan secara tertulis kepada MKDKI atau Majelis Kehormatan Disiplin Kedokteran Indonesia agar sengketa tersebut dapat segera diselesaikan.

\section{SARAN}

Untuk pihak rumah sakit, agar tenaga kesehatan yang melakukan pelayanan kesehatan terhadap pasien harus mampu melayani dengan cepat karena mungkin pasien memerlukan penanganan segera, serta penanganan pertama dari perawat harus mampu membuat pasien menaruh kepercayaan 
bahwa pengobatan yang diterima dimulai secara benar.

\section{DAFTAR PUSTAKA}

Abdul Kadir Muhammad. (2004). Hukum dan Penelitian Hukum, PT. Citra Aditya Bakti, Bandung.

Amir Syamsudin, Berita Negara Republik Indonesia, diunduh tanggal 29 Juli 2015 dari : http:ditjenpp.kemenkumham.go.id

As'ad Sunggu. (2014). Kode Etik Profesi Tentang Kesehatan, Sinar Grafika, Jakarta.

Bhekti Suryani. (2013). Panduan Yuridis Penyelenggaraan Praktik Kedokteran, Dunia Cerdas, Jakarta.

Danny Wiradharma. (1996). Hukum Kedokteran, Binarupa Aksara, Jakarta.

Djaja S. Meliala. (2012). Hukum Perdata Dalam Perspektif $B W$, Nuansa Aulia, Bandung.

M. Jusuf Hanafiah dan Amri Amir. (2013). Etika Kedokteran Dan Hukum Kesehatan, Buku Kedokteran EGC, Jakarta.

Soekidjo Notoatmodjo. (2010). Etika dan Hukum Kesehatan, Rineka Cipta, Jakarta, 2010.

Undang-Undang No.29 Tahun 2004 tentang Praktik Kedokteran

Undang-Undang Nomor 44 Tahun 2009 tentang Rumah Sakit.

Undang-Undang Republik Indonesia No.36 Tahun 2009 tentang Kesehatan. 